\title{
Brief interventions for reducing drinking in veterans with Hepatitis $C$
}

Bret Fuller

\author{
From $1^{\text {st }}$ International Congress on Neurobiology and Clinical Psychopharmacology and European \\ Psychiatric Association Conference on Treatment Guidance \\ Thessaloniki, Greece. 19-22 November 2009
}

The prevalence of hepatitis $\mathrm{C}(\mathrm{HCV})$ infection among veterans treated within Veterans Affairs Medical Centers (VAMCs) is 3 to 4 times higher than the general population prevalence of $1.8 \%$. Approximately 50 to $60 \%$ of patients with $\mathrm{HCV}$ are at risk for progression to endstage liver disease. The risk for progression to end-stage liver disease is significantly increased in individuals with heavy alcohol consumption and veterans with $\mathrm{HCV}$ have a high rate of co-morbid alcohol use. Treatments that reduce or eliminate alcohol consumption among $\mathrm{HCV}$-positive veterans may reduce the impact of the disease for the individual.

Motivational enhancement treatments (MET) have shown the greatest efficacy in treating alcohol use disorders in general. Further, medications that reduce alcohol craving and consumption, that are also not metabolized in the liver are equally beneficial. The objectives of this presentation are to detail two ongoing studies at the Veterans Affairs Medical Center that aim to reduce alcohol consumption for veterans with hepatitis C. The first study assesses the efficacy of MET to reduce number of drinking days over the period of six months. This study is being conducted in two VA Medical Centers and compares a four session MET intervention to a four session educational (control) intervention. The second study being conducted at three VA medical centers assesses the use baclofen, a generic medication approved for use in muscle spasm that has been shown in initial trials to reduce alcohol craving and consumption. Baclofen is not metabolized in the liver and is potentially ideal for patients with HCV. Both non-medication and medication interventions are crucial strategies for improving the health of veterans with $\mathrm{HCV}$ who have co-morbid alcohol use.

$\overline{\text { NW Hepatitis C Resource Center and Staff Psychologist, Portland VA Medical }}$ Center, Portland, Oregon, USA
Published: 22 April 2010

doi:10.1186/1744-859X-9-S1-S79

Cite this article as: Fuller: Brief interventions for reducing drinking in veterans with Hepatitis C. Annals of General Psychiatry 2010 9(Suppl 1):S79.
Submit your next manuscript to BioMed Central and take full advantage of:

- Convenient online submission

- Thorough peer review

- No space constraints or color figure charges

- Immediate publication on acceptance

- Inclusion in PubMed, CAS, Scopus and Google Scholar

- Research which is freely available for redistribution

Submit your manuscript at www.biomedcentral.com/submit
C Biomed Central 